Daria R. Yunda

master's degree student

Elena Yu.Pishkova

candidate of philological sciences, assosiate professor Institute of Philology, Journalism and Intercultural Communication FSAEI of HE "Southern Federal University" Rostov-on-don, Rostov region

\title{
METHODS OF TRANSLATING NON-EQUIVALENT LEGAL VOCABULARY
}

Abstract: the article touches upon a subject of non-equivalent vocabulary. Translating legal terms, which primarily include legal realias, denoting concepts, that are not present in the target language, is a rather difficult procedure.

Keywords: non-equivalent vocabulary, legal translation.

\section{Юнда Дарья Руслановна магистрант \\ Пишкова Елена Юрьевна}

канд. филол. наук, доцент, преподаватель

Институт филологии, журналистики и межкультурной коммуникации ФГАОУ ВО «Южный федеральный университет» г. Ростов-на-Дону, Ростовская область

DOI $10.31483 / r-97502$

\section{СПОСОБЫ ПЕРЕВОДА БЕЗЭКВИВАЛЕНТНОЙ ЮРИДИЧЕСКОЙ ЛЕКСИКИ}

Аннотация: в статье рассматривается феномен безэквивалентной лексики. Особую трудность представляет перевод юридической терминологии, представленной в первую очередь юридчческими реалиями, которые обозначают понятия, отсутствующие в ПЯ.

Ключевые слова: безэквивалентная лексика, юридический перевод. 
Legal translation is usually considered as field-specific translation. A translator may have some problems while translating English legal vocabulary into Russian. First of all, this is due to the significant differences between English and Russian legal systems, which belong to different legal branches: Anglo-Saxon and Civil law. The main thing a translator needs to do is to carry out an adequate translation of a source language unit by means of a corresponding unit of the target language. However, two cases may arise while translating English legal terms:

1) when there is an appropriate equivalent in the target language to adequately convey a foreign term;

2) when there is no appropriate equivalent in the target language to convey a foreign term [Grinev, 1993: 460].

If there occurs a situation, when a foreign term has several equivalents in the target language, a translator must choose the most appropriate unambiguous translation of a legal term.

The main thing a translator needs to do while translating English legal vocabulary into Russian is to find an equivalent term, the meaning of which in the target language will be identical to the meaning of the English term.

While translating legal vocabulary, that does not have corresponding equivalents in the target language, we can use two approaches:

1) if in the target language there are no specific equivalents, which are identical to the original legal term, it is recommended to introduce new words and terms in the target text;

2) if in the target language there are legal terms, which are similar to the original lexical unit, a translator should check, how they correspond to the original term [Ivanova, Kosonogova, 2013: 21].

In the article «Peculiarities of translating legal terms and realia in fictional films» D.V. Litvina focuses on the use of specific legal realias, which are defined as «a set of the legal sphere material objects, corresponding to material objects and persons», and form a significant amount of non-equivalent vocabulary. D.V. Litvina offers the following classification of legal realias. 
1. Posts, professions, titles (coroner, solicitor, sheriff)

2. The judiciary (Supreme Court)

3. State and public organizations (American Bar Association)

4. Legal documents (brief, subpoena)

5. Collections of laws

6. Artifacts (gavel)

7. Law enforcement organizations (the Justice Department, police) [Litvina: 147].

For an adequate translation of legal realias a translator should be deeply acquainted with the legal systems of the target and source languages. O. V. Kosonogova and M.V. Malashchenko studied the American law terminology and distinguished a special group of terms, that form a non-equivalent vocabulary, in other words, terms, that contain an onymic component (a proper name):

1) an eponymic term - a term, the name of which contains a proper name, most often, the person from whose name the term was formed. For example, the Henry VIII clause is a clause of Henry VIII, that gives the executive branch the right to amend the law;

2) a toponymic term - a term derived from a toponym. For example, YorkAntverp rules are rules in maritime law, according to which all parties involved in a sea venture must proportionately share in any losses that result from sacrifices made to the cargo to save the remainder [Kosonogova, Malashenko].

S.V. Grinev distinguishes four main methods of translating non-equivalent legal vocabulary:

1. Borrowing a foreign term while meeting the target language rules of transcription and transliteration: felony - фелония (the category of serious crimes, which are between treason and misdemeanor according to the degree of danger); misdemeanor мисдиминор (the category of the least dangerous crimes, touching upon administrative offenses).

2. Calque translation: Lynch Law - закон Линча. It was named in honor of the magistrate judge in the United States, who made the decision on the death penalty 
without a court trial during the War of Independence [Ivanov, Kosonogova, 2013: 29_30]

3. Word-for-word translation with word order change: Special Investigation Division - отдел особых расследований.

4. Descriptive translation: a perp walk- практика, применяемая американскими правоохранительными органами по отношению к преступнику или подозреваемому в совериении преступления. As a rule, alleged criminals are placed in public view, thereby providing an opportunity for journalists to take pictures and cover the event in the media. This practice is mainly specific for New York city.

In addition to the above methods of translating non-equivalent legal vocabulary, D.V. Litvina distinguishes such methods as:

1) specification;

2) search for a functional analogue;

3) holistic transformation (omissions and additions);

4) periphrasis [Litvina: 149].

As articulated earlier, modern legal documents use a large number of Latinism or Latin expressions, which are particularly problematic for a translator due to their belonging to non-equivalent vocabulary. If a Latin word or phrase is understandable without translation, then you need not translate it and can leave it in its original form in the target text. However, when the meaning of a Latin expression is not clear, a translator needs to give an explanation in parentheses [Ivanova, Kosonogova, 2013: 22].

Thus, translating non-equivalent legal vocabulary is particularly problematic for a translator due to the differences, that exist in the legal systems of different countries. Therefore, to achieve an adequate translation, it is necessary to take into consideration how accurately the lexical unit of the target language corresponds to the original one and reveals its essence.

\section{Сиисок литературы}

1. Литвина Д.В. Особенности перевода юридических терминов и реалий в художественных фильмах. - М.: Московский государственный университет им. М.В. Ломоносова. 
2. Колянда Д.Н. Юридический дискурс. Некоторые особенности «Legalese» при переводе юридических терминов. - С. 311-315.

3. Косоногова О.В. Национально-маркированные и национально-немаркированные терминонимы в англо-американской терминологии права / О.В. Косоногова, М.В. Малащенко; Южный федеральный университет.

4. Косоногова О.В. Юридический дискурс: лингвопрагматика имени собственного // Знание. Понимание. Умение. - 2008. - №2. - С. 188-192.

5. Иванова Д.Н. Legal Translation Practice. Юридический перевод: учебное пособие по английскому языку / Д.Н. Иванова, О.В. Косоногова, Г.С. Пшегусова. - Ростов н/Д: Изд-во Южного федерального университета, 2013. - 304 с.

\section{REFERENCES:}

1. Litvina D.V. Peculiarities of translating legal terms and realia in feature films. - Moscow: Lomonosov Moscow State University.

2. Kolyanda D.N. Legal discourse. Some features of «Legalese» in the translation of legal terms. - pp. 311-315.

3. Kosonogova O.V. Legal discourse: linguopragmatics of the proper name.Knowledge. Understanding. Skill. - 2008. - No. 2. - p. 188-192.

4. Kosonogova O.V., Malashchenko M.V. Country-specific and country-unmarked terminonyms in the Anglo-American terminology of law. - Southern Federal University.

5. Ivanova D.N., Kosonogova O.V., Pshegusova G.S. «Legal Translation Practice». Legal translation: a textbook on the English language. Rostov-on-Don: Southern Federal University Press, 2013, 304 p. 